\title{
Age-related changes in the testicular and antler cycles of reindeer, Rangifer tarandus
}

\author{
N. Leader-Williams \\ British Antarctic Survey, Natural Environment Research Council and \\ Department of Clinical Veterinary Medicine, Madingley Road, Cambridge, CB3 OET, U.K.
}

\begin{abstract}
Summary. A total of 111 male reindeer of various ages was shot in all months of the year to study the relationship between the seasonal changes in testicular activity and the antler cycle. From the changes in testis weight, seminiferous tubular tissue area and plasma testosterone values and the occurrence of spermatogenesis, it is concluded that calves attain physiological puberty in their first year, during which they also complete an antler cycle. The amplitude of the cyclical change in testis weight and plasma testosterone values increases with age and can be correlated with the earlier onset of events in the spermatogenic and antler cycles of older animals. The duration of the spermatogenic and testosterone cycles of reindeer is short, and is inversely related to the long period spent without antlers. It is suggested that testosterone strongly influences the antler cycle of reindeer males.
\end{abstract}

\section{Introduction}

The antler cycle of the Eurasian reindeer and North American caribou (Rangifer tarandus) male has two interesting features, the completion of one antler cycle during the first year of life and a delay of up to 4 months between casting of the old and regrowth of the new antlers. Furthermore, reindeer and caribou are the only species in which the females carry antlers, and the comparison between the antler cycles of the two sexes is of interest. The early work of Tandler (1910) and Tandler \& Grosz (1913) suggests that the events of the antler cycles of both sexes are largely independent of the activity of the gonads, as castration of reindeer has a minimal effect on the normal antler cycle, in contrast to other species of deer so far studied (reviewed by Goss, 1963).

Previous studies of reindeer and caribou males have considered only one aspect of reproductive physiology, such as testis weight and histology (Meschaks \& Nordkvist, 1962; McEwan, 1963) and plasma testosterone (Whitehead \& McEwan, 1973). The present study correlates observations on both the testis and testosterone levels with the antler cycles and provides the first complete account of events occurring in the first year of life.

\section{Materials and Methods}

\section{Study area}

The study was undertaken on South Georgia, a subantarctic island lying between $53^{\circ} 30^{\prime}$ and $55^{\circ} \mathrm{S}$ and $35^{\circ} 30^{\prime}$ and $38^{\circ} 30^{\prime} \mathrm{W}$. Norwegian reindeer were introduced onto the island in 1911 and 1925, and now form three discrete herds-the Barff, Royal Bay and Busen herds (LeaderWilliams, 1978). The reindeer reversed their breeding season 2 years after their transfer across the equator, and now calve in November, the austral spring (Olstad, 1930). The rut occurs in the last 2 weeks of March and the first 2 weeks of April. 


\section{Field studies}

The male reindeer of various ages were shot through the heart, chest or neck between May 1974 and November 1975. Of this sample of 111 from the Barff herd, 4 reindeer had abnormal testes and epididymides and are reported separately (Leader-Williams, 1979a). Immediately after shooting, blood samples from 95 males were collected into $10 \mathrm{ml}$ evacuated tubes coated with lithium heparin (Vacutainers: Becton-Dickenson, Wembley, U.K.). The sample was taken from, in descending order of preference and depending on the placing of the shot, the jugular vein, the anterior vena cava, the left ventricle or the posterior vena cava. The samples were returned to the field laboratory up to $10 \mathrm{~h}$ after collection, and centrifuged for 2-3 min at $200 \mathrm{~g}$. The plasma was stored at $-25^{\circ} \mathrm{C}$ until analysis.

Antlers were classified as follows: never grown, growing in velvet, cleaning the velvet, partly clean (having desiccated tatters of velvet at the tips), hard, or cast. During the course of a full dissection of each animal, the testes and epididymides were removed by cutting the spermatic cord level with the most proximal part of the caput epididymidis. The combined testis and epididymis weights for both sides were obtained on spring balances to the nearest $0.5 \mathrm{~g}$ up to 3.0 $\mathrm{g}$, and thereafter to the nearest gram; those at $0.5 \mathrm{~g}$ were at the limits of accuracy of field weighings. The carcass weight $(\mathrm{kg})$ was obtained after removal of the gastrointestinal tract and antlers. A transverse slice (about $3 \mathrm{~mm}$ thick) of testis and one epididymis from each animal was then fixed in Bouin's solution within $8 \mathrm{~h}$ of death, although usually much sooner, and transferred to $70 \%$ methanol 2 days later.

\section{Laboratory studies}

Age determination. The ages of the reindeer were determined by a combination of tooth eruption patterns and annulations in decalcified sections of incisor teeth (Leader-Williams, 1979b). The age in years was assumed to increase by 1 on 15 November (the midpoint of the month of birth) and the age in months to increase on the 15th day of each month. Data from the same months of the 2 years of the study are combined to present the annual cycle. Reindeer were assigned to the following groups: A, <1-12 months (calves); B, 13-24 months (yearlings); C, 25-36 months (adults); D, 37 months and over (adults). As there were only 27 males in Group $D$ (the oldest was 71 months), those shot in the same month are treated together for analysis (e.g. animals 37, 49 and 61 months old are combined as the ' +1 ' month class).

Histology. A total of 62 histological sections of testis and cauda epididymidis (at least one representative specimen of each available month class) was processed in the routine manner for light microscopy. The sections were examined at a magnification of $\times 100$ and measurements were made with an image analysing computer (Quantimet 720 ). Each section was assigned a random number, which was decoded only after examination of all the sections.

The spermatogenic activity of the testis was assessed by measuring the total area (A) of each of 20 tubules cut in transverse section, and the proportion of tissue ( $\mathrm{t}$ ) within that tubule; the seminiferous tubular tissue area was calculated using $(A \times t)$. At the same time the presence or absence of spermatids in each tubule was noted. An index of spermatogenesis was derived from the numbers of tubules out of 20 containing spermatids; an index of 5 or over was considered to indicate full spermatogenesis.

The cauda epididymidis was scored for the presence or absence of spermatozoa and the presence of spermatozoa with polymorphs. The period of fertility was considered to end when polymorphs and other cellular debris, including immature cells, appeared after the rut and spermatozoa became sparse and more densely stained.

Testosterone assay. Plasma testosterone concentrations were assayed using the specific radioimmunoassay of Corker \& Davidson (1978), which does not involve chromatography. The antiserum cross-reacted with $5 \alpha$-dihydrotestosterone (23.9\%), $11 \beta$-hydroxytestosterone $(0.4 \%)$, oestradiol-17 $\beta(0.2 \%)$ and androstenedione $(0 \cdot 1 \%)$. The lower detection limit of the assay was 
$0.4 \mathrm{ng} / \mathrm{ml}$. In order to validate results from young males ( $<14$ months) in which values were below or close to the lower detection limit, a second assay, which included a chromatographic purification step, was performed. This involved extraction of $0.5 \mathrm{ml}$ plasma with hexane :ether $(4: 1 \mathrm{v} / \mathrm{v})$ and separation in a Celite column using $10 \%$ ethyl acetate in isoctane as solvent (Stone, Kharma, Nakamura, Mishell \& Thorneycroft, 1971). The recovery of testosterone, assessed by using a tritiated testosterone tracer was $74.7 \pm 1.61 \%(n=30)$. With such recoveries the detection limits of the assay were from 0.1 to $5.0 \mathrm{ng} / \mathrm{ml}$. All 21 samples in the first assay with undetectable levels of testosterone had levels of $0.4 \mathrm{ng} / \mathrm{ml}$ or less in the second assay; the inter-assay variation in the remaining 9 samples was $11 \pm 4.3 \%$.

Statistical treatment of data. Testis and epididymis weights of $<1$ - and 1-month-old animals which were at the limits of accuracy of field weighings were excluded from statistical analysis. Mean testis and epididymis weights were calculated for at least 4 samples and compared by Student's $t$ test; significance levels of means with different variances were calculated as described by Snedecor \& Cochran (1967). To eliminate changes in testis and epididymis weights that might be solely due to changes in body weight in Group A, a ratio of testis and epididymis weight $(\mathrm{g})$ to carcass weight $(\mathrm{kg})$ was used.

\section{Results}

\section{Testis and epididymis}

Weight. With the exception of the 4 males with abnormal testes (Leader-Williams, 1979a), $92 \%$ of males had identical left and right combined testis and epididymis weights; the mean variation in the remaining $8 \%$ was $8 \pm 2 \cdot 2 \%$. Text-figure 1 shows the changes in the combined left testis and epididymis weights of 107 normal reindeer with age.

In Groups B, C and D the testis and epididymis weights were at a peak from February to May, and at their lowest from July to December. There were no significant differences $(P>$ 0.05 ) between the minimum mean left testis and epididymis weights from animals of each group collected from 15 July to 15 December: Group B, $10.9 \pm 0.8 \mathrm{~g}(\mathrm{~N}=11)$; Group C, $13.0 \pm 1.3$ $\mathrm{g}(\mathrm{N}=5)$; Group $\mathrm{D}, 12.0 \pm 1.0 \mathrm{~g}(\mathrm{~N}=8)$. The maximum mean weights from animals collected from 15 February to 15 May (Group B, $24.6 \pm 2.6 \mathrm{~g}(\mathrm{~N}=7)$; Group C, $34.6 \pm 3.2 \mathrm{~g} \mathrm{(N=7);}$ Group $\mathrm{D}, 49.7 \pm 3.8 \mathrm{~g}(\mathrm{~N}=10))$ showed a significant difference between Groups $\mathrm{B}$ and $\mathrm{C}(t=$ 2.41 , d.f. $=12, P<0.05)$ and Groups $\mathrm{C}$ and $\mathrm{D}(t=2.83$, d.f. $=15, P<0.02)$. Therefore, whilst the minimum weights of the testis and epididymis did not alter, there was an amplitudinal increase in the cycle with increasing age, i.e. an approximately 2-, 3- and 4-fold increase in Groups B, C and D respectively. The maximum increase found was 8-fold (an 80-g left testis and epididymis from a 52-month-old male).

There was also a cyclical increase and decrease in testis and epididymis weight in Group A (Text-fig. 1). These changes, and those in the ratios of testis and epididymis weight to carcass weight, for combined month classes of Group A (Table 1), showed that the increase in testis and epididymis weight from birth to 8 months of age could not be attributed solely to the rapid growth of calves in their first summer. However, the cyclical weight change in Group A showed differences from that occurring in Groups B, C and D, in that (a) the peak in weight occurred from June to September and did not coincide with the rut, so that the period when weights were minimal was delayed by over 1 month compared with other groups; (b) the peak in weight in individual animals was not highly synchronized, 2 testes and epididymides of $13 \mathrm{~g}$ having been collected from males shot as far apart as 14 June and 5 September; (c) the testis and epididymis were showing growth as well as cyclical change, because the minimum mean weight of 10 - to 12 month-old males was significantly lower $(t=4.56$, d.f. $=15, P<0.001)$ than that in Group B. 


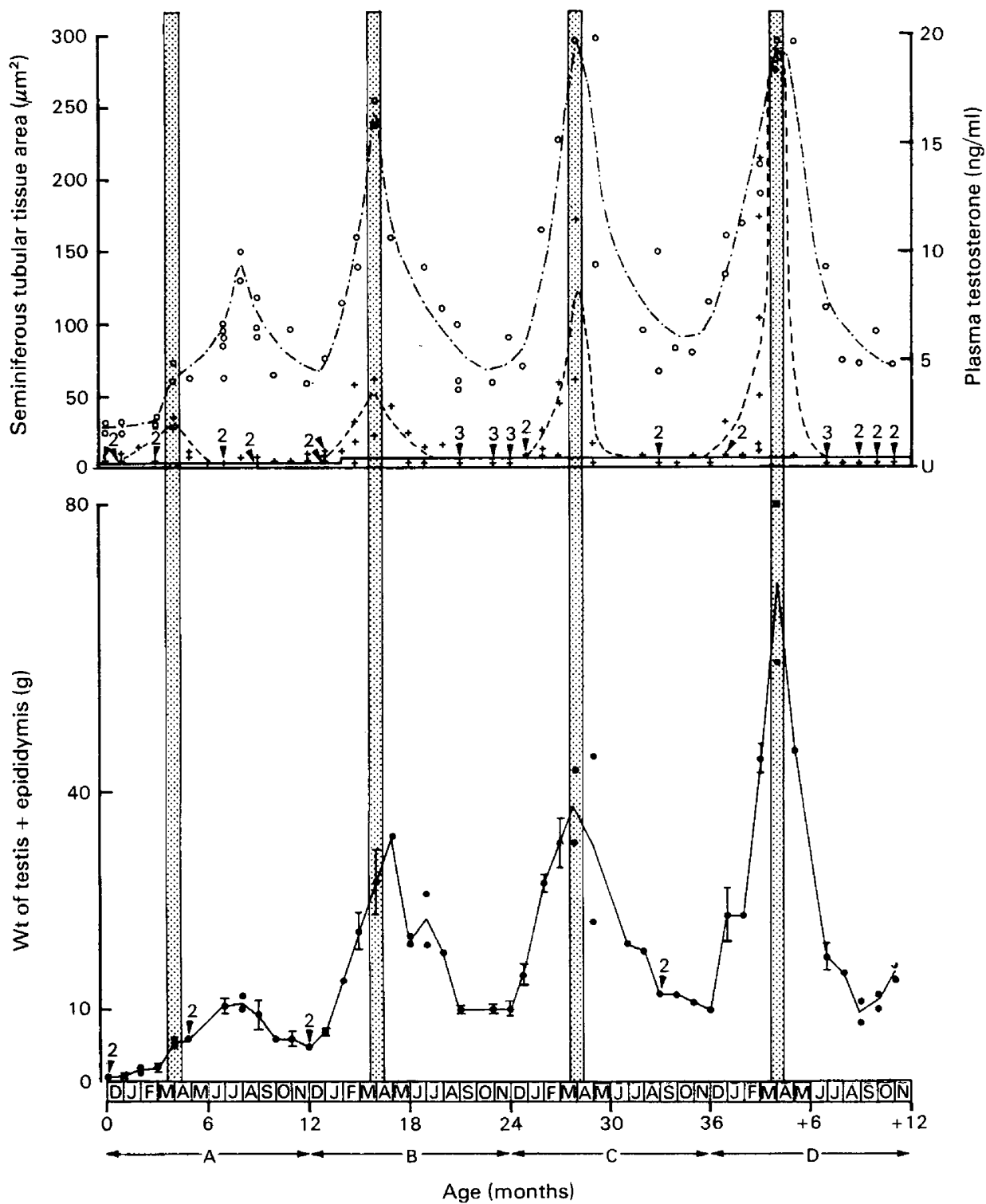

Text-fig. 1. Variations in left testis and epididymis weight ( for 3 or more males per month class; adjacent means or single observations joined by straight line); plasma testosterone concentration $(+----+)$; and seminiferous tubular tissue area $(\mathrm{O}-\cdot-\cdot \mathrm{O})$ in reindeer with age (Groups A to D). Arrows show numbers of animais at each point when these are $<4$ and $>1$. The stippled bars indicate the periods of rut.

Histology. The results of the timing of spermatogenesis and the presence of spermatozoa in the epididymis (Text-fig. 2) show that in Groups C and D production of spermatids begins, and spermatozoa appear in the epididymis, 1 month before the rut, whereas in Group B these events coincided with the start of the rut. Only in Groups B and C were a few polymorphs present with the first spermatozoa in the epididymis. The production of spermatids ceased after July in Groups B and C, but probably earlier in Group D; spermatozoa, mostly degenerative and few in number, were present in the epididymis with polymorphs and cellular debris until September in 
Groups C and D and until November in Groups B. The cyclical changes in seminiferous tubular tissue area, drawn with a curve fitted by inspection (Text-fig. 1), showed that peak values occurred in these groups around the time of the rut. However, the amplitude of this cycle did not increase markedly with age, the increase being about 2.5-, 3- and 3-fold in Groups B, C and D respectively.

Table 1. Changes in the mean \pm s.e.m. weight of the testis and epididymis of reindeer calves related to age and carcass weight

\begin{tabular}{|c|c|c|c|c|c|}
\hline $\begin{array}{c}\text { Age } \\
\text { (months) }\end{array}$ & $\begin{array}{c}\text { No. } \\
\text { of } \\
\text { animals }\end{array}$ & $\begin{array}{l}\text { Left testis + } \\
\text { epididymis } \\
\text { weight } \\
\text { (g) }\end{array}$ & $P$ & $\begin{array}{l}\text { Left testis }+ \\
\text { epididymis weight/ } \\
\text { carcass weight } \\
(\mathrm{g} / \mathrm{kg})\end{array}$ & $P$ \\
\hline 1 & 6 & $1 \pm 0$ & - & $0.06 \pm 0.002$ & - \\
\hline $2+3$ & 5 & $2.0 \pm 0.35\}$ & $<0.001$ & $0.09 \pm 0.005\}$ & $<0.001$ \\
\hline $4+5$ & 4 & $5.8 \pm 0.25\}$ & $<0.02$ & $0.19 \pm 0.011\}$ & $<0.002$ \\
\hline 7 & 6 & $10 \cdot 0 \pm 1 \cdot 12\}$ & $<0.02$ & $0.30 \pm 0.017\}$ & $<0.002$ \\
\hline $8+9$ & 5 & $10.0 \pm 1.38\}$ & N.S. & $0.32 \pm 0.047\}$ & N.S. \\
\hline $10,11,12$ & 6 & $5.7 \pm 0.50\}$ & $<0.05$ & $0.18 \pm 0.019\}$ & $<0.02$ \\
\hline
\end{tabular}

In Group A, 10 specimens from males of 7-9 months of age (when testis and epididymis weights were maximum) were examined. Spermatids were present in the seminiferous tubules of both males of 8 months and spermatozoa in the epididymis of one male of 9 months (Text-fig. 2). Furthermore, there was a clear cyclical increase and decrease in seminiferous tubular tissue area (Text-fig. 1). From birth to 3 months, when tubular tissue area was lowest, the tubules had a ring of supporting cells at their periphery, a few gonocytes and no lumen, the tubules consisting of over $90 \%$ tissue. At 4 to 5 months, the tubular tissue area began to increase, and a lumen appeared. At 7 months, after a further increase in tubular tissue area, there were spermatogonia and Sertoli cells with some primary spermatocytes, and areas of vacuolation in the tubular tissue, as well as a lumen. At 8 months of age, 4 months after the rut, the tubular tissue area was at its greatest, about 3 times that at birth. The two 9-month-old specimens, lacking spermatozoa in their epididymides, had spermatocytes and cells undergoing division in the tubules; the specimen with epididymal spermatozoa showed signs of tubular regression and sloughing of tissue from the basement membrane, as did those of 10 and 11 months. By 12 months of age the tubules were becoming reorganized with a peripheral ring of spermatogonia.

Testosterone. The plasma testosterone concentrations found in reindeer of various ages are shown in Text-fig. 1, using results from the second assay for males under 14 months, and a curve fitted by inspection. There was a cyclical rise and fall in testosterone levels, with peak values occurring at the rut in all groups. There was a marked increase in the amplitude of the cycle with increasing age; testosterone was at undetectable or very low levels from July to December, rising to peak values in March of $2 \cdot 3,4 \cdot 1,11.5$ and $19.3 \mathrm{ng} / \mathrm{ml}$ in Groups A, B, C and D respectively.

\section{The antler cycle}

The results of the observations on the antlers of the individual males and the overall pattern of the antler cycle, based on these, and corroborated by general observations made in all 3 herds, are shown for the 4 age groups in Text-fig. 2.

With increasing age, the events of the antler cycle tended to occur earlier in the year. The most marked trend occurred with the period of antler casting, there being about 3 months' difference between Groups A and D. The earlier onset of cleaning the velvet resulted in the antlers of older animals being completely clean before the rut, whereas in Group A cleaning began during the rut. Furthermore, Group D spent more time with cast antlers (10-15 weeks) 


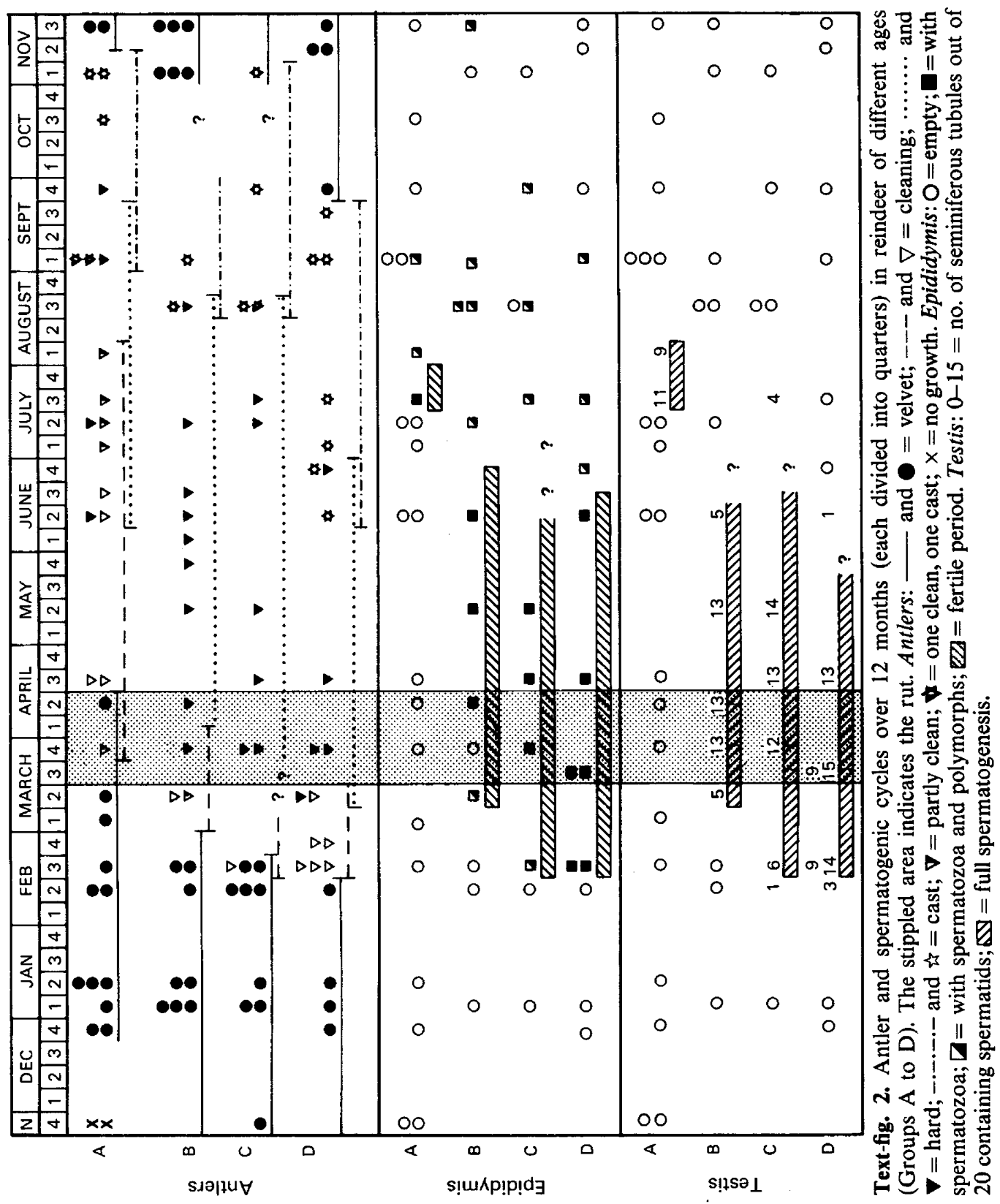


and velvet antlers (19 weeks) and less time with hard antlers (12-15 weeks) than did Groups B and C (cast: 9-11 weeks; velvet: 14-17 weeks; hard: 19-20 weeks). In Group A there were no antlers present during the first month of life, and they had a long and imprecise period of antler cleaning (10-18 weeks) and spent less time with cast (7-10 weeks) or hard antlers (11-14 weeks) than did Groups B and C.

\section{Discussion}

In the bull (Davies, Mann \& Rowson, 1957) and the red deer, Cervus elaphus (Lincoln, 1971a), physiological puberty has been defined as the period between the initial onset of androgenesis and the first appearance of spermatozoa in the testis. Some South Georgian reindeer do not produce spermatids at 8 months of age, but the present study provides clear evidence of testicular weight change, of an androgenic cycle and of spermatogenic activity (histological changes in the seminiferous tubules and an increase in tubular tissue area) throughout Group A (Text-fig. 1). Thus all the reindeer studied are considered as effectively attaining puberty at 4-8 months of age. However, puberty occurs at 17-18 months of age in barren-ground caribou (McEwan, 1963) and wild reindeer (Sokolov, 1959, quoted by McEwan, 1963). McEwan (1963) based his statement on the first appearance of spermatids in the testis, although he recorded a cycle of spermatogenic activity in calves. Whitehead \& McEwan (1973) also recorded a rise in plasma testosterone values at 4-5 months of age in 2 captive hybrid reindeer $\times$ caribou calves. Therefore it may be concluded that an androgenic cycle and spermatogenic activity are a normal occurrence in Rangifer calves, even though spermatids may not always be produced, and puberty is therefore believed to occur consistently in the species at 4-8 months of age.

However, with the exception of the antlers, none of the secondary sexual characters listed by Lincoln (1971a) for red deer, such as neck girth or rutting odour, was found in the calves shot in this study. Rutting behaviour, known to be largely under the control of testosterone in red deer (Lincoln, Youngson \& Short, 1970), was not observed in reindeer calves on South Georgia, or by those who have investigated systematically the rutting behaviour of Rangifer (Espmark, 1964; Lent, 1965; Bergerud, 1973). Thus if the definition of puberty had included the development of all secondary sexual characters and reproductive behaviour, reindeer could not be said to complete puberty in their first year. Furthermore, the period of breeding (Dauphine \& McClure, 1974; Bergerud, 1975) and calving (Nowasad, 1975; Holthe, 1975) is well synchronized in Rangifer, usually lasting not more than 1 month, so the appearance of spermatids in the testes of non-libidinous calves 3 months after the rut can be of little direct reproductive value. However, yearling male Rangifer do show development of their secondary sexual characters, have spermatozoa in their epididymides at the rut (Text-fig. 2) and display rutting behaviour, though their breeding success is limited by the presence of older, more dominant males (Espmark, 1964; Bergerud, 1973). The indirect reproductive consequence of physiological puberty in calves may be to ensure the testis is fully functional in yearlings. In adapting to high latitudes the species has a short and intense rut, which occurs during migration in caribou (Lent, 1965), and yearlings may play a significant role in matings at the end of the rut, when many adult males. are exhausted.

Chaplin \& White (1972) found a progressive increase in peak testis and epididymis weights in fallow deer (Dama dama) from calves to yearlings (due to the occurrence of puberty in yearlings) and from yearlings to adults (cause unexplained), but no significant weight increases between adults of different age classes. In the present study there is a progressive increase in the amplitude of the cycle of both combined testis and epididymis weight and plasma testosterone values from Group A to Group D, but little increase in seminiferous tubular tissue areas from Groups B to D (Text-fig. 1). In studies of other cervids (Short \& Mann, 1966; Lincoln, 1971b; Chaplin \& White, 1972; Mirachi, Scanlon \& Kirkpatrick, 1977a) maximum testis weights were from 5 to 10 times heavier than epididymis weights, and the epididymis contributed little to their combined cyclical weight increase. If reindeer are similar in this respect, it can be concluded that 
the increased amplitude of the weight cycle from Group B to Group D is due mainly to an increase in the secretory activity, and hence weight, of the interstitial tissue with age. The weight increase from Group A to Group B, whilst the testis is still growing, is probably due to an increase of both tubular and interstitial components. As testis weights and plasma testosterone are at basal levels for similar periods in Groups B to D (Text-fig. 1), it follows that the relative rates of increase and of decrease of these parameters in relation to time increases with age. These findings support the suggestion of Lincoln (1971a) of a progressive increase in testosterone secretion with age in red deer. Such an increase could explain both the earlier onset of rutting behaviour in older reindeer males and their more dominant position in a hierarchy at this time (Espmark, 1964), and the age-related shifts seen in rutting behaviour and in the response of accessory and secondary sexual characters in other species (Lincoln et al., 1970).

Testicular activity and testosterone levels have been correlated with events of the antler cycle in several species (roebuck, Capreolus capreolus: Short \& Mann, 1966; red deer; Lincoln, 1971a,b; white-tailed deer, Odocoileus virginianus: Wislocki, 1943; Mirachi et al., 1977a; Mirachi, Scanlon, Kirkpatrick \& Schreck, 1977b). However, Goss (1963) and Bubenik (1975) interpreted early accounts of castration in reindeer (Tandler, 1910; Tandler \& Grosz, 1913; Hadwen \& Palmer, 1922) as indicating that testosterone plays an insignificant role in the male antler cycle. The present study shows that antler growth in Groups B to D begins at, or after, the spring equinox (Text-fig. 2), when testis weights and testosterone levels are minimal; that cleaning occurs as testis weights and testosterone levels are rising, and that casting occurs subsequent to their decrease. These observations are consistent with the hypothesis that the presence of testosterone is important to the normal antler cycle of male Rangifer also. Tandler (1910), Meschaks \& Nordkvist (1962) and Bergerud (1976) noted that casting of antlers of male reindeer and caribou occurs sooner after the rut with increasing age; a less pronounced trend occurs with other events of the cycle (Whitehead \& McEwan, 1973; Text-fig. 2), and similar observations have been made for other species (Goss, 1963). The age-shift in the onset of spermatid production in Groups B to D clearly parallels that of antler cleaning (Text-fig. 2), suggesting that the latter process also occurs earlier in older males in response to a higher relative rate of testosterone increase. Similarly, antler casting occurs earlier in older males which have a higher relative rate of testosterone decrease after the rut.

Regrowth of antlers begins soon after casting in most deer; however, Rangifer and Odocoileus (Wislocki, 1943) both have prolonged periods without antlers. It is recognized that various methods have been used in studies of different species of cervid (Table 2) and that some authors have used single plasma samples (Whitehead \& McEwan, 1973; Mirachi et al., 1977b;

Table 2. Comparison of duration of testicular cycles and of antler cycle events in different species of cervid

\begin{tabular}{|c|c|c|c|c|c|c|}
\hline \multirow[b]{2}{*}{ Species } & \multicolumn{5}{|c|}{ Months when: } & \multirow[b]{2}{*}{ Source } \\
\hline & $\begin{array}{l}\text { Plasma } \\
\text { testosterone } \\
>4 \mathrm{ng} / \mathrm{ml}\end{array}$ & $\begin{array}{c}\text { Testicular } \\
\text { testosterone } \\
>10 \mu \mathrm{g} / 100 \mathrm{~g}\end{array}$ & $\begin{array}{l}\text { Spermatids in } \\
\text { seminiferous } \\
\text { tubules }\end{array}$ & $\begin{array}{l}\text { Antlers are } \\
\text { hard }\end{array}$ & $\begin{array}{l}\text { Antlers are } \\
\text { cast }\end{array}$ & \\
\hline $\begin{array}{l}\text { Capreolus } \\
\text { capreolus }\end{array}$ & - & 7 & 6 & 8 & 1 & Short \& Mann (1966) \\
\hline $\begin{array}{l}\text { Cervus } \\
\text { elaphus }\end{array}$ & - & 7 & 9 & 8 & $<1$ & Lincoln (1971b) \\
\hline $\begin{array}{l}\text { Odocoileus } \\
\quad \text { virginianus }\end{array}$ & 3 & - & 6 & 4 & 2 & $\begin{array}{l}\text { Wislocki (1943), } \\
\text { Mirachi et al. } \\
\text { (1977b) }\end{array}$ \\
\hline $\begin{array}{l}\text { Rangifer } \\
\quad \text { tarandus }\end{array}$ & 2 & - & 4 & $3 \frac{1}{2}$ & 4 & $\begin{array}{l}\text { Whitehead \& McEwan } \\
\text { (1973), } \\
\text { this study }\end{array}$ \\
\hline
\end{tabular}


present study), not allowing for episodic testosterone secretion (Katongole, Naftolin \& Short, 1974; Lincoln \& Kay, 1979). However, the data indicate an inverse relationship between the length of the period spent without antlers and the length of the testosterone and spermatogenic cycles, reinforcing the suggestion that testosterone influences the antler cycle of male Rangifer.

It has been assumed that pedicle development and completion of one antler cycle in the first year of life occurs prepubertally in Rangifer (Bubenik, 1975), in contrast to other species in which both events depend on the first sexual cycle (Blauel, 1935; Wislocki, Aub \& Waldo, 1947; Lincoln, 1971a). The present study demonstrates the possibility of such a relationship in male reindeer and caribou, though it has yet to be proved by the castration of young calves before antler development. It is notable also that the first antler cycle of reindeer shows a similar anomaly to that of red deer (Lincoln, 1971a). Cleaning is a lengthy process, and once initiated (presumably by increased testosterone), both it and casting are completed long after testosterone has decreased to very low levels (Text-figs 1 and 2). This implies the involvement of a second factor, which, if overridden by the presence of testosterone in older males, could explain the apparent occurrence of an antler cycle in castrated males (Tandler, 1910). Furthermore, if this second hormone is common to females, the occurrence of an antler cycle in them may also be explained.

I thank Mr R. M. Pratt for assistance with fieldwork, Professor R. V. Short, F.R.S., for providing facilities for testosterone assays; Mrs $R$. Cunningham for instruction in assay techniques; Dr H. M. Dott for use of his image analysing computer; Dr G. A. Lincoln and Dr H. M. Dott for helpful criticism of an early draft; and Dr J. P. Croxall and Dr R. M. Laws for their comments on the manuscript.

\section{References}

Bergerud, A.T. (1973) Movement and rutting behaviour of caribou, Rangifer tarandus, at Mount Albert, Quebec. Can. Field-Nat. 87, 357-369.

Bergerud, A.T. (1975) The reproductive season of Newfoundland caribou. Can. J. Zool. 53, 12131221.

Bergerud, A.T. (1976) The annual antler cycle in Newfoundland caribou. Can. Field-Nat. 9, 449463.

Blauel, G. (1935) Beobachtungen uber die Enstenung der Perucke biem Rehbock. Endokrinologie 15, 321329.

Bubenik, A.B. (1975) Taxonomic value of antlers in genus Rangifer. Biol. Papers Univ. Alaska, Spec. Rep. 1, 41-63.

Chaplin, R.E. \& White, R.W.G. (1972) The influence of age and season on the activity of the testes and epididymides of the fallow deer, Dama dama. J. Reprod. Fert. 30, 361-369.

Corker, C.S. \& Davidson, D.W. (1978) The radioimmunoassay of testosterone in various biological fluids without chromatography. J. Steroid Biochem. 9. 373-374.

Dauphine, T.C. \& McClure, R.L. (1974) Synchronous mating in Canadian barren-ground caribou. J. Wildl. Mgmt 24, 250-258.

Davies, D.V., Mann, T. \& Rowson, L.E.A. (1957) Effect of nutrition on the onset of male sex hormone activity and sperm formation in monozygous bull-calves. Proc. R. Soc. B 147, 332-351.

Espmark, Y. (1964) Rutting behaviour in reindeer (Rangifer tarandus L.). Anim. Behav. 12, 159-163.
Goss, R.J. (1963) The deciduous nature of deer antlers. In Mechanisms of Hard Tissue Destruction, pp. 339-369. Ed. R. Sognnaes. Am. Assoc. Adv. Sci. Pub. 75., Washington, D.C.

Hadwen, S. \& Palmer, L.J. (1922) Reindeer in Alaska. U.S. Dept. Agric. Bull. No. 1089.

Holthe, V. (1975) Calving season in different populations of wild reindeer in south Norway. Biol. Papers Univ. Alaska, Spec. Rep. 1, 194-198.

Katongole, C.B., Naftolin, F. \& Short, R.V. (1974) Seasonal variations in blood luteinizing hormone and testosterone levels in rams. J. Endocr. 60, 101-106.

Leader-Williams, N. (1978) The history of the introduced reindeer of South Georgia. Deer 4, 256-261.

Leader-Wiliams, N. (1979a) Abnormal testes in reindeer, Rangifer tarandus. J. Reprod. Fert. 57, 127-130.

Leader-Williams, N. (1979b) Age determination of reindeer introduced into South Georgia. J. Zool., Lond. 188 (in press).

Lent, P.C. (1965) Rutting behaviour in a barren-ground caribou population. Anim. Behav. 13, 331-336.

Lincoln, G.A. (1971a) Puberty in a seasonally breeding male, the red deer stag (Cervus elaphus L.). $J$. Reprod. Fert. 25, 41-54.

Lincoln, G.A. (1971b) The seasonal reproductive changes in the red deer stag (Cervus elaphus). $J$. Zool., Lond. 163, 105-123.

Lincoln, G.A. \& Kay, R.N.B. (1979) Effects of season on the secretion of $\mathrm{LH}$ and testosterone in intact and castrated red deer stags (Cervus elaphus). $J$. Reprod. Fert. 55, 75-80. 
Lincoln, G.A., Youngson, R.W. \& Short, R.V. (1970) The social and sexual behaviour of the red deer stag. J. Reprod. Fert., Suppl. 11, 71-103.

McEwan, E.H. (1963) Reproduction of barren-ground caribou, Rangifer tarandus groenlandicus Linnaeus, with relation to migration. Ph.D. thesis, McGill University, Montreal, Quebec.

Meschaks, P. \& Nordkvist, M. (1962) On the sexual cycle in the reindeer male. Acta vet. scand. 3, 151162.

Mirachi, R.E, Scanlon, P.F. \& Kirkpatrick, R.L. (1977a) Annual changes in spermatozoan production and associated organs of white-tailed deer. $J$. Wildl. Mgmt 41, 92-99.

Mirachi, R.E., Scanlon, P.F., Kirkpatrick, R.L. \& Schreck, C.B. (1977b) Androgen levels and antler development in captive and wild white-tailed deer. $J$. Wildl. Mgmt 41, 178-183.

Nowasad, R.F. (1975) Reindeer survival in the Mackenzie Delta herd, birth to four months. Biol. Papers Univ. Alaska, Spec. Rep. 1, 199-208.

Olstad, O. (1930) Rats and reindeer in the Antarctic. Det. Norske Videnskaps-Akademi i Oslo. Sci. Res. Norwegian Antarctic Expeditions 4, 1-19.

Short, R.V. \& Mann, T. (1966) The sexual cycle of a seasonally breeding mammal, the roebuck (Capreolus capreolus). J. Reprod. Fert. 12, 337-351.

Snedecor, G.W. \& Cochran, W.G. (1967) Statistical Methods, 6th edn. Iowa State University Press, Ames, Iowa.
Sokolov, I.I. (1959) [Fauna of U.S.S.R.: Mammals I.] Academy of Science, Leningrad.

Stone, S., Kharma, K.M., Nakamura, R.M., Mishell, D.R. \& Thorneycroft, I.H. (1971) A technique for the assay of 17-hydroxyprogesterone (17-hydroxy4-pregnene-3,20-dione) in serum using Celite column chromatography and competitive protein binding. Steroids 18, 161-173.

Tandler, J. (1910) Bericht uber den Einfluss der Geshlechtsdrusen auf die Geweihbilding bei Rentieren. Anz. kaiserl. Akad. Wiss. Wein, Math.-naturw. Kl. 47, 252-257.

Tandler, J. \& Grosz, S. (1913) Die biologischen Grundlagen der sekundaren Geschlechtscharaktere. Springer, Berlin.

Whitehead, P.E. \& McEwan, E.H. (1973) Seasonal variation in the plasma testosterone concentration of reindeer and caribou. Can. J. Zool. 51, 651-658.

Wislocki, G.B. (1943) Studies on the growth of deer antlers. II. Seasonal changes in the male reproductive tract of the Virginia deer (Odocoileus virginianus) with a discussion of the factors controlling the antlergonad periodicity. In Essays in Biology, in Honor of Herbert M. Evans, pp. 631-653. University of California Press, Berkeley.

Wislocki, G.B., Aub, J.C. \& Waldo, C.M. (1947) The effects of gonadectomy and the administration of testosterone propionate on the growth of antlers in male and female deer. Endocrinology 40, 202-224.

Received 18 December 1978 